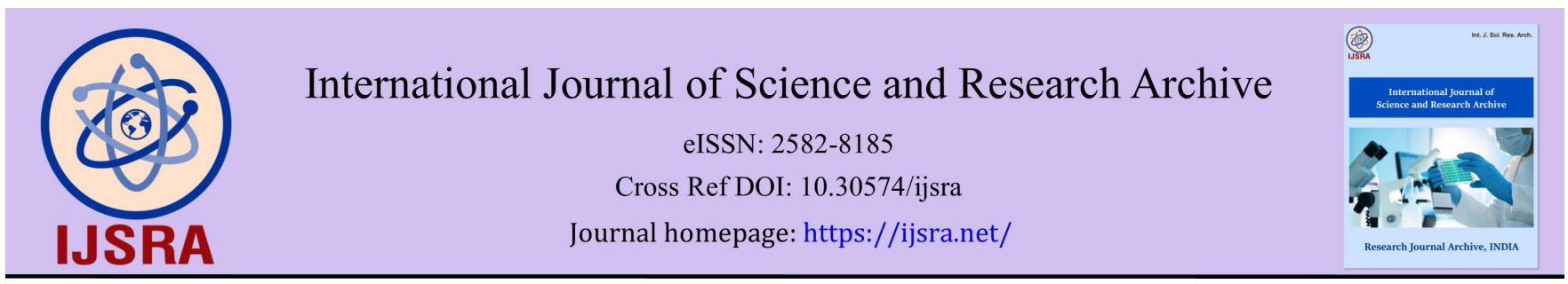

(REVIEW ARTICLE)

\title{
The Nigerian population: A treasure for national development or an unsurmountable national challenge
}

\author{
Vitalis Jafla Pontianus ${ }^{1}$ and Oruonye E.D. ${ }^{2}{ }^{*}$ \\ ${ }^{1}$ Department of Sociology, Taraba State University, Jalingo, Nigeria. \\ 2 Department of Geography, Taraba State University, Jalingo, Nigeria.
}

International Journal of Science and Research Archive, 2021, 02(01), 136-142

Publication history: Received on 02 January 2021; revised on 06 Februay 2021; accepted on 08 Februay 2021

Article DOI: https://doi.org/10.30574/ijsra.2021.2.1.0026

\begin{abstract}
Nigeria is the most populous black nation in the world. It is equally one of the Less Developed Countries (LDCs) with very high population. Population growth is a very important element and a challenge in the development process in LDCs. The population of Nigeria is expected to continue to grow up to 239 million by 2025 and 440 million by 2050 , thereby ranking it to 4th position among countries of the World with high population. This without doubt will place Nigeria in a position of major player in the global system, and more importantly in the African region. It is against this background that this study examines Nigeria's population composition by poising the following questions; will Nigeria's present and future population structure be a benefit or a burden? How can Nigeria's relative share of working-age composition (15- 64) and dependents (under 15 and 65 and over) contribute to long term economic growth and development of the country? The findings of the study reveals that population growth is a critical factor in the development of any economy, providing workforce for production of goods and services to boost economic development and a critical determinant of the potentials of a country's investment. The study findings also show that continuous population growth militates against economic growth through inducement of poverty, falling medical care/services and environmental degradation, worsen resource scarcity in areas where a large proportion of the population already relies on natural resource-based livelihoods. The study argued that population increase is not a problem in itself to any nation, and that there are some impeding factors associated with population growth such as corruption, inadequate planning, inappropriate implementation of development plans, poor budget/implementation and complacency in developing human capital. These are issues that the Nigerian state since independence have continued to battle with which has invariably made it a seemingly failed state. The study concludes that how much any country can benefit from its population size is dependent on the quality of human capital. Based on the findings, the study recommends economic diversification, government empowerment of Small and Medium scale Enterprises, paying attention to human capital development and target-oriented education.
\end{abstract}

Keywords: Human capital; National challenge; National development; Population growth and Population theory.

\section{Introduction}

Nigeria is the most populous nation in Africa. It is the most populous black nation in the world, and indeed one of the highly populated nations of the Less Developed Countries (LDCs). According to the Nigerian National Population Commission (NPC, 2013) Nigeria's population was 169. 28 million in 2013. And it increased to 173.938 million in 2014 (NPC, 2014). This placed Nigeria in the seventh most populous country in the world in 2014 (IMF, 2014). To some scholars, continuous growth in the population of the LDCs constitute a challenge for several reasons: (i) considerable proportion of the population is largely dependent and unproductive, (ii) the proportion of the population that is trained

\footnotetext{
* Corresponding author: Oruonye E.D

Department of Geography, Taraba State University, Jalingo, Nigeria.

Copyright $(2021$ Author(s) retain the copyright of this article. This article is published under the terms of the Creative Commons Attribution Liscense 4.0.
} 
is relatively insignificant, and (iii) the proportion of the population that can contribute to research and development (R\&D), by way of development of technology, is relatively insignificant (Cincotta \& Engelman, 1997; Karev, 2002; Prettner \& Trimbon, 2012).

Conversely, some scholars such as Bucci (2008) and Bottone and Sena (2011) argued that increasing population is very important in the development process of LDCs because labour or human capital is a major component in the production process. They however argue that the population is a blessing if a large part of such population constitutes well-trained and informed human capital (Adewole, 2012; Isola \& Alani, 2012). Such training that is required involves investment in education and health, which is an effective way a nation's population can be transformed into a strong and efficient labour stock with high potentials for economic productivity. Scholars such as Uche, Ihugba and Nwosu (2013) observed that if the government increases expenditure on education, with efficient management of the resources, it will result in a more viable human capital stock, and that will enhance productivity and growth. This study examines the Nigerian population in terms of whether it is a dividend or a setback toward socio-economic growth and development of the country.

\section{Population and Population Theory}

According to Blanchet (1991), there are three (3) major views to the population-economic growth nexus, namely; the population pessimistic, the population optimistic, and the population neutralist views. The population pessimistic view was the view held by the adherents of the Malthusian school of thought. This school of thought was named after Thomas Malthus, the proponent of the theory. Thomas Malthus argued in his classical work titled "An Essay on the Principle of Population", that continuous increase in population will bring an economy to a standstill if urgent measures are not put in place to check this (Aidi, Emecheta \& Ngwudiobu, 2016). Malthus insisted that more population means more mouths to be fed and that since the population was growing (at geometric progression) at a faster rate than food supply (growing at arithmetic progression), this disequilibrium will adversely affect the economy. This position was corroborated by scholars like Coale and Hoover (1958) and Ehrlich (1968) who observed that rapid population growth has the tendency to impact negatively on the economy since it will overwhelm any induced response by technological progress and capital accumulation.

The population optimistic view which was propounded by the renowned Danish economist, Esther Boserup (1981) argued that contrary to the negative relationship between population and economic growth acclaimed by the Malthusian theorists, a rapidly growing population will impact positively on an economy because a rapidly growing population will make room for the economics of scale as well as the promotion of technological and institutional innovations (Kuznets, 1967). The followers of this theory strongly counter the Malthusian's position of inevitable future food shortage (resulting from population expansion) by explaining that advancement in technology will positively influence productivity thus neutralizing any potential threat of growing population on food supply. Boserup argued that population determines agricultural methods. According to Boserup, agricultural methods and productivity of food depends on the size of the population. To Boserup, necessity is the mother of invention and humanity would always find a way out.

The population neutralist theorists came up with a view that was completely different from the two schools of thought mentioned earlier. They population neutralist noted that population growth has no single-handed influence on the available resources. Bloom and Freeman (1986) observed that population neutralist theorists contended that population growth in isolation (from other factors) has neither a positive nor negative impact on economic growth. According to Kelley (1988), population neutralism is a doctrine positing the absence of any significant relationship between population growth and the rate of economic growth. Some scholars such as Sachs and Warner (1995) went a step further to test this empirically and observed that the perceived negative correlation between population growth and economic growth becomes unobservable once other variables (such as country size, openness to trade, level of educational attainment, social and political stability among others) are excluded in the model. The population neutralist view dominated the thinking of scholars about population growth in the last half-century (Kelley, 2001).

\section{Nigerian Demographic Projections}

Although there have been observed declining fertility in Nigeria, the country's population is expected to continue to grow to 239 million by 2025 and 440 million by 2050 due to population momentum. This will make the country to be the 4th most populous country in the World (United Nations, 2012). Most of this expected growth will be among the working age component of the population, between age 15 and 64 years. Thus, the dependency ratio, or the number of children and elderly (under age 15 and over age 65) divided by the number of working-age adults (between ages 15- 
64), will fall over this period from 88 dependents per 100 workers in 2010 to only 69 dependents per 100 workers by 2050. The median age component of the total population is most likely to increase from 17.9 to 21.4 years over the 40 years from 2010 to 2050 (United Nations, 2012). These anticipated growth pattern is of great importance because Nigeria is expected to make up three percent of the total world population and 14 percent of Africa's population by 2050 (United Nations, 2009). This without doubt will place Nigeria in a position of major player in the global system, and more importantly in the African region.

Will Nigeria's current and future population composition be a benefit or a burden? How can Nigeria's relative share of working-age composition (15- 64) and dependents (under 15 and 65 and over) contribute to long term economic growth and development? The economic growth potential posed by the demographic transition is created by a decline in mortality that precedes a large decline in infertility. This period of lower mortality and higher fertility, often known as a baby boom, will ultimately lead to a working-age bulge or a potential demographic dividend when this large cohort of children grows up (Holly \& Blessing, 2014). However, whether the working-age bulge constitutes a dividend or not also depends on the availability of employment. A country's dividend cannot be realized if there is widespread unemployment among its working-age population. This is because those outside the labour force consume part of what is produced by the currently employed component, and this influences the amount of surplus that is available for investment after consumption. A larger surplus can lead to increased investment and increased economic growth, therefore, assuming that jobs are available. Hence, a lower dependency ratio is an advantage.

\section{Critique on Population Growth and Demographic Dividend}

When it became clear in the late 19th century that both the early classical theory and neoclassical theory of growth could not survive the empirical scrutiny of the time, neoclassical economists came up in the literature with human capital theory in the 1960s. Scholars such as Solow (1956), Schultz (1961), and Grossman (1972), as pointed out by Campbell and Agbiokoro (2014), tried to establish the linkage of human capital with economic growth and the countryby-country development differences. In an effort to elucidate the inter-country divergences in growth, Solow (1956) growth theory underlined the fact that the rate of growth of any economy is a function of technological accumulation. Solow however, ignored the fact that technology is driven by human capital; on its own, it cannot result into economic growth. Technology is engineered, developed, and improved upon by human capital; hence, human capital remains the bedrock of sustainable development (Campbell \& Agbiokoro, 2014).

Bremner, López-Carr, Suter and Davis (2010) observed that continuous population growth militates against economic growth through the inducement of poverty, falling medical care/services, as well as environmental degradation. The Health and educational needs of a large number of young people will generally reduce household savings rates and reduce investments in production activities (Adewole, 2012). Furthermore, high fertility lowers female labour force participation and thus tends to decrease household income (Bremner et al, 2010). Finally, population growth may aggravate resource scarcity in places where a large proportion of the population already depends on natural resourcebased livelihoods including, agriculture, grazing, forest products, and fishing for income and subsistence on marginal lands and less productive natural ecosystems (MEA, 2005 cited in Bremner et al, 2010).

In addition to the strain on the natural resource base, the increasing population also creates challenges for the equitable provisioning of adequate schooling, material resources, and civic order, thereby straining social conditions. Degraded social order limits problem-solving for environmental problems, causing further strain (Harte, 2007). Bremner et al (2010) therefore concluded that empirical research on the impact of population growth on poverty is still largely inconclusive. Ukpong, Ekpebu and Ofem (2013) also saw population growth as being inimical to economic growth through poverty aggravation. In their work entitled "Cointegration Inferences on Issues of Poverty and Population Growth in Nigeria", Ukpong et al (2013) observed that the poverty rate rises as the population increased, meaning that a rise in population will induce an increase in poverty level. Again, they found the economic growth - poverty relationship to be negative, indicating economic growth - population growth negative relationship. Their study findings have revealed that population growth has been underlined as one of the main causes of poverty in most nations of the world, especially underdeveloped countries, including Nigeria (WHES, 2012, IFAD, 2013). Increased population put enormous pressure on a nation by influencing the demand level of the people for basic necessities of life. In situations where a nation's population growth is rapid, for example, the propensity that there would be increase in demand for food, shelter, employment, infrastructure, healthcare, education will also increase in the same direction. Hence, the consideration of rapid growth in population is a challenge on economic growth especially in the face of inadequate resources available (WHES, 2012).

Ukpong et al (2013), on the other hand, maintained that: population growth remains a critical factor in the development of any economy, and where it is not properly managed, could increase the scourge of poverty in the economy. Population 
growth can be a useful factor in providing a workforce for the production of goods and services to boost economic development and it remains a critical determinant of the potential of a country's investment. It is important to note that, an increase in population alone may not necessarily increase poverty incidence in a country, when one considers the situation in China, and other countries, that have experienced considerable economic growth over the last decades notwithstanding their large population size (Banister, Bloom \& Rosenberg, 2012). Some scholars have argued and attempted to establish empirically, that population increase is not a problem in itself to any nation, and that there are some constraining factors associated with population growth such as corruption, inadequate planning, inappropriate implementation of development plans, poor budget/implementation, complacency in developing human capital (Bongaarts, 1994). These are issues that the Nigerian state since independence have continued to battle with which has invariably made the most populous Black Nation on earth and the giant of Africa a seemingly failed state (Kinnan, Gordon, DeLong, Jaquish \& McAllum, 2011).

In line with this, Adetiloye and Adeyemo (2012) equally observed that high population growth in an economy with falling and/or inadequate real investment in assets and capital formation (which include investment in education and health) will lead to increased poverty and negative economic growth. Adewole (2012) in his work, "Effect of Population on Economic Development in Nigeria: A quantitative Assessment" also maintained that, the consequences of a high population growth are to retard all development efforts in Nigeria unless accompanied by a high rate of capital accumulation and technological progress." Schutz $(1961 ; 1992)$ and Dennis (1962) argued that the quality of the population is a crucial factor of production and that this quality can only be a product of investment in education and health. Bloom and Canning (2003) supported this assertion because health is a direct component of man's wellness as well as part of the human capital set that builds an individual's capabilities.

Isola and Alani (2012) lent support to developed human capital as an agent of national development in any country of the world. Adapting the growth accounting model in their work: "Human Capital Development and Economic Growth: Empirical Evidence from Nigeria", their findings showed that growth in qualitative population set will only amount to an improvement in the economic wellbeing of Nigerians. Grossman (1972), Schultz (1992), Bloom and Canning (2000, 2003), and Isola (2002) variously argued that the quality desired which can translate into economic growth is only a question of ensuring an educated and a healthy population.

Adelakun (2011) held that Nigeria need not really worry about the increase in the population size but should rather engage a pragmatic approach in developing their capabilities since it should be considered a very veritable economic growth transmitter. Adelakun explained that human capital remains the rallying point where all resources are converted into functional forms for man's use and benefit. Findings of the study by Adelakun (2011) on human capital development and economic growth in Nigeria, reveals a positive relationship between human capital development and economic growth for Nigeria, arguing that the percentage of this relationship, though significant, was not strong due to a high degree of illiteracy and healthcare shortage.

Furthermore, Awe and Ajayi (2010) reported positive relationship and directional causation for human capital investment and economic growth, but with a strong call for conscious and pragmatic investment in education and health. Prettner and Trimbon (2012) observed with emphasis the fact that building a viable human capital is necessary, but not a sufficient condition for gaining from population growth. They stressed that a viable labour stock at all levels has to grow progressively with the growth in the manufacturing sector together with a deepening technology through R\&D.

Thus, any demographic change without growth in production and technological progress may result in poverty (that is, a fall in per capita income), a high degree of dependency, inequality, and dwindling economic progress. In analyzing economic growth fluctuations vis-à-vis population growth in Nigeria, Nwosu, Dike and Okwara (2014) found a positive (significant) impact of population growth on economic growth. Employing time series data spanning 1960 to 2008, Nwosu et al (2014) found out that, apart from the significant impact, there is a long-run equilibrium relationship between economic growth and population growth and also, an indication of unidirectional causality between these variables.

Paul (2015) equally agrees with the argument that population growth in itself is not a curse, since all other resources required for economic growth are driven by the availability of human capital. The implication of this, is that how much any country can benefit from its population size is dependent on the quality of human capital. Where human capital development efforts are dwindling in the face of increasing population, then adverse consequences on economic growth should be expected (Nwosu et al, 2014). This has been an issue of great concern to most Nigerians given the number of months spent by most Nigerian youths out of school as a result of the Academic Staff Union of Universities (ASUU) strike that has become a national festival in the national life of the Nigerian tertiary institutions. This is because a growing population size without corresponding growth in the development of human capital will only increase the rate of 
dependence and consumption and will eventually bring about a falling rate of household savings, falling rate of per capita income as well as very low productivity (Bucci, 2015).

From the foregoing, it is inferred that the economic growth of a nation could be dependent on the growth of its population, but the effect or impact can be either negative or positive depending on the availability of certain factors and conditions - improved technology (R \& D), functional human capital development programs, and adequate and functional infrastructure.

\section{Conclusion}

This study has examined the Nigerian population in the light of a treasure for National development or an unsurmountable national challenge. The findings of the study reveals that population growth is a critical factor in the development of any economy, providing workforce for production of goods and services to boost economic development and a critical determinant of the potentials of a country's investment. The study findings also show that continuous population growth militates against economic growth through inducement of poverty, falling medical care/services and environmental degradation, worsen resource scarcity in areas where a large proportion of the population already relies on natural resource-based livelihoods. The study argued that high population growth is not a problem in itself to any nation, and that there are some constraining factors associated with population growth such as corruption, inadequate planning, inappropriate implementation of development plans, poor budget/implementation and complacency in developing human capital. These are issues that the Nigerian state since independence have continued to battle with which has invariably made it a seemingly failed state. The study concludes that how much any country can benefit from its population size is dependent on the quality of its human capital.

\section{Recommendations}

Based on the findings of the study, the following recommendations are made;

- There is need to develop policy structure that drives a target-oriented education, training, and health care which must be sustained.

- The unstable nature of the Nigerian university system that experiences strike action almost every year, must be given due and prime attention by the government so as to enhance and support a steady growth in the human resource capacity of the nation which is necessary to make the growing population an economic tool for economic development.

- Government implementation of minimum wages across the nation can become an incentive to the working class of the population to help them remain focused. This can help Nigeria's population, in combination with its relative wealth, to be a dynamic engine of growth if harnessed properly.

- Economic diversification and government empowerment of Small and Medium scale Enterprises should be considered a key agenda to government at all levels.

- Nigerians must develop a strong sense of patriotism and patronize home grown food and Nigerian made goods to increase her national GDP.

\section{Compliance with ethical standards}

\section{Acknowledgments}

The authors express their appreciation to all the authors whose materials was used in this work.

\section{Disclosure of conflict of interest}

The authors hereby affirmed that there is no any conflict of interest in this publication.

\section{References}

[1] Adelakun OJ. Human Capital Development and Economic Growth in Nigeria. European Journal of Business and Management. 2011; 3(9). 
[2] Adetiloye KA, Adeyemo KA. Domestic Investment, Capital Formation, and Population Growth. Developing Country Studies. 2012; 2(7).

[3] Adewole AO. Effect of Population on Economic Development in Nigeria: A Quantitative Assessment. International Journal of Physical and Social Sciences. 2012; 2(5).

[4] Aidi HO, Emecheta C, Ngwudiobu IM. Population and Economic Growth in Nigeria: is there an Empirical Evidence of Causality? International Journal Advances in Social Science and Humanities. 2016; 4(2); 59-66.

[5] Awe AA, Ajayi SO. The Nexus Between Human Capital Investment and Economic Growth in Nigeria. Pakistan Journal of Social Sciences. 2010; 7(1): 1-7.

[6] Banister J, Bloom DE, Rosenberg L. Population Aging and Economic Growth in China. In: Aoki M., Wu J. (eds) The Chinese Economy. International Economic Association Series. Palgrave Macmillan, London. 2012.

[7] Blanchet D. On interpreting the observed relationship between population growth and economic development: A graphical exposition. Population and Development Review. 1991; 17: 105-114.

[8] Bloom DE, Freeman RB. Economic development and the timing and components of population growth. Journal of Policy Modelling. 1986; 10: 57-81.

[9] Bloom DE, Canning D. The Health and Wealth of Nations, Science. 2000; 287(18): 1207-1209.

[10] Bloom DE, Canning D. The health and poverty of nations: from Theory to Practice. Journal of Human Development. 2003; 4(1): 47-7.

[11] Bongaarts J. Can the Growing Human Population Feed Itself? Scientific American. 1994; 270 (3): 36-42.

[12] Boserup E. Population and technological change: A study of long-term trends. University of Chicago Press. 1981.

[13] Bottone G, Sena V. Human Capital: Theoretical and Empirical Insights. American Journal of Economics and Sociology. 2011; 70(2): 401-423.

[14] Bremner J, López-Carr D, Suter L, Davis J. Population, Poverty, Environment, and Climate Dynamics in the Developing World. Interdisciplinary Environmental Review. 2010; 11(2/3): 112-126.

[15] Bucci A. Product Proliferation, Population, and Economic Growth. Journal of Human Capital. 2015; 9(2): $170-197$.

[16] Campbell 0, Agbiokoro T. Human Capital and Economic Growth: A Three-Stage Least Squares Approach. Journal of Economics and Sustainable Development. 2014; 5(5).

[17] Cincotta RP, Engelman R. Economics and Rapid Change: The Influence of Population Growth. Population Action International. 1997.

[18] Coale AJ, Hoover E. Population growth and economic development in low-income countries. Princeton, New Jersey, Princeton University Press. 1958.

[19] Dennis EF. Sources of Economic Growth in the United States and the Alternatives Before Us. Committe of Economic Development. New York, USA. 1962.

[20] Ehrlich PR. Population control or race oblivion: The population bomb. New York, Ballantine Books. 1968.

[21] Grossman. On the Concept of Health Capital and the Demand for Health. The Journal of Political Economy. 1972; 80(2): 223-255.

[22] Harte J. Human Population as a dynamic factor in environmental degradation, Journal of Population and environment Vol 28 (4-5) Kluwer Academic Publishers. 2007; 223-236.

[23] Holly ER, Blessing UM. Capitalizing on Nigeria's demographic dividend: reaping the benefits and diminishing the burdens. African Population Studies. 2014; 27(2): 319-330.

[24] International Fund for Agricultural Development (IFAD. Rural Poverty in Africa. 2013.

[25] International Monetary Fund (IMF). World Population and Demographics Studies. 2014.

[26] Isola WA. The Economic Education Linkage: Evidence from Nigeria (1980-1999). Lagos Journal of Educational Administration and Planning. 2002; 2 (1): 16-32.

[27] Isola WA, Alani RA. Human Capital Development and Economic Growth: Empirical Evidence from Nigeria. Asian Economic and Financial Review. 2012; 2(7): 813-827. 
[28] Karev GP. (2002). Dynamics of Inhomogeneous Population and Global Demography Models. Oak Ridge Institute for Science and Education, National Institute of Health. 2002.

[29] Kelley AC. The economic consequence of population changes in third world countries. Journal of Economic Literature. 1988; 26(4): 685-728.

[30] Kelley AC. The population debate in historical perspective: Revisionism revised. Oxford University Press. 2001.

[31] Kinnan C, Gordon D, DeLong M, Jaquish D, McAllum R. Failed State 2030: Nigeria-A Case Study Air University Press. 2011; 9-20.

[32] Kuznets S. Population and economic growth. Proceedings of the American Philosophical Society. 1967; 111: 170193.

[33] MEA. Ecosystems and Human Well-being: Synthesis, Millennium Ecosystem Assessment Synthesis Reports, Island Press, Washington DC. 2005.

[34] Nwosu C, Dike A0, Okwara KK. The Effects of Population Growth on Economic Growth in Nigeria. International Journal of Engineering and Science. 2014; 3 (11): 7-18.

[35] Paul Mombert. Optimum Population Size. Population and Development Review. 2015; 41(1): 147-150.

[36] Prettner K, Trimborn T. (2012). Demographic Change and R\&D-Based Economic Growth: Reconciling Theory and Evidence. Centre for European Governance and Development Research, University of Gottingen, Germany. 2012.

[37] Sachs JD, Warner AM. Natural resource abundance and economic growth. NBER Working Paper No: 5398.1995.

[38] Shultz TP. Education and Economic Growth: Social Forces Influencing American, Education. Ed. N.B. Henry Chicago. National Society for the Study of Education. University of Chicago Press. 1961.

[39] Schultz TP. The Role of Education and Human Capital in Economic Development: An Empirical Assessment. Yale Economic Growth Center Discussion Papers Series. 1992; 670.

[40] Solow R. A Contribution to the Theory of Economic Growth. The Quarterly Journal of Economics. 1956; 70(1): 65-94.

[41] Uche E, Ihugha OA, Nwosu C. Causal Relationship between Nigeria Government Budget Allocation to the Education Sector and Economic Growth". Discourse Journal of Educational Research, www.resjournals.org/IJER. 2013; 1(8): 54-64.

[42] Ukpong IG, Ekpebu ID, Ofem NI. (2013). Cointegration Inferences on Issues of Poverty and Population Growth in Nigeria. Journal of Development and Agricultural Economics. 2013; 5(7): 277 -283.

[43] United Nations. (2009). World Urbanization Prospects: The 2009 Revision. Population Division of the Department of Economic and Social Affairs of the United Nations Secretariat, New York. 2009.

[44] United Nations. World Population Prospects: The 2012 Revision. Population Division of the Department of Economic and Social Affairs of the United Nations Secretariat. 2012.

[45] World Hunger Education services (WHES). World Hunger and Poverty Facts and Statistics. World Hunger Education Services. 2012. 